\title{
ORGANIZACJE SIECIOWE W PROCESACH ZARZĄDZANIA TURYSTYKĄ WIEJSKĄ
}

\author{
Arkadiusz Niedziółka', Dariusz Bartosik ${ }^{2}$ \\ ${ }^{1}$ Uniwersytet Rolniczy w Krakowie, Wydział Rolniczo-Ekonomiczny \\ ${ }^{2}$ Szkoła Wyższa im. Bogdana Jańskiego, Wydział Zarządzania w Warszawie
}

\begin{abstract}
Streszczenie: Turystyczne organizacje sieciowe i inne sieci uczestniczą w procesach zarządzania turystyką wiejską w Polsce, stosując różne koncepcje i metody zarządzania. Do najaktywniejszych organizacji sieciowych zarządzających rozwojem turystyki na obszarach wiejskich można zaliczyć: stowarzyszenia agroturystyczne, lokalne organizacje turystyczne i lokalne grupy działania. Celem pracy jest określenie najczęściej stosowanych koncepcji zarządzania w turystyce wiejskiej przez wymienione organizacje. Praca ma charakter teoretyczno-badawczy. Zastosowaną metodą badawczą była metoda analizy i krytyki piśmiennictwa, którą przeprowadzono w okresie od marca do kwietnia 2020 roku. Poddano krytycznej analizie pozycje naukowe związane z przedstawioną problematyką. Na ich podstawie wyszczególniono najczęściej stosowane przez badane sieci koncepcje zarządzania w rozwoju turystyki wiejskiej.
\end{abstract}

Słowa kluczowe: agroturystyka, organizacje sieciowe, turystyka wiejska, zarządzanie

DOI: $10.17512 /$ znpcz.2020.3.02

\section{Wprowadzenie}

Sieć” jest pojęciem, które na trwałe weszło do języka potocznego oraz znalazło stabilne miejsce w światowej literaturze naukowej. Nieskrępowane upowszechnienie się słowa ,sieć” w naukach społecznych, języku potocznym, gospodarce oraz technologii oznacza istotną zmianę epistemologiczną i nie jest tylko chwilową modą językową (Czakon 2012, s. 21). Sieć to zbiór aktorów połączonych zbiorem więzi. Aktorzy to członkowie organizacji sieciowej, powiązani wzajemnie różnymi relacjami, współpracujący ze sobą i odnoszący dzięki członkostwu w sieci wymierne korzyści.

Organizacja sieciowa, nazywana również przedsiębiorstwem sieciowym, to zbiór niezależnych w sensie prawnym jednostek gospodarczych (aktorów w sieci), współpracujących na różnych polach z innymi członkami sieci oraz realizujących wspólne przedsięwzięcia i inwestycje. Sieci cechuje m.in. niski poziom hierarchiczności, dobrowolność przystąpienia do niej, elastyczność, dążenie do współdziałania, długoterminowy (strategiczny) charakter współpracy między uczestnikami sieci, wspólne korzystanie z zasobów przez aktorów sieci oraz korzyści wynikające ze współpracy (efekt synergii) (Barczak 2016, s. 59).

${ }^{1}$ Arkadiusz Niedziółka, dr, arkadiusz.niedziolka@urk.edu.pl, ORCID: 0000-0003-2546-4154

${ }^{2}$ Dariusz Bartosik, mgr, dariuszbartosik77@ gmail.com, ORCID: 0000-0003-3703-8371 
Sieci występują w każdym sektorze gospodarki, np. w przemyśle czy szeroko rozumianych usługach. Wśród usług ważne dla gospodarek wielu krajów są usługi turystyczne i hotelarskie. Podstawowe, najważniejsze usługi turystyczne to usługi noclegowe, gastronomiczne oraz transportowe. Natomiast do usług uzupełniających w turystyce, określanych również mianem usług towarzyszących lub komplementarnych, zalicza się najczęściej usługi rekreacyjno-sportowe, kulturalno-rozrywkowe oraz informacyjne (Oleksiuk 2007, s. 107). Na całym świecie usługi turystyczne często świadczone są przez różne turystyczne organizacje sieciowe, np. sieci i łańcuchy hotelarskie czy inne organizacje turystyczne zrzeszające wielu członków (aktorów) świadczących zarówno podstawowe, jak i uzupełniające usługi turystyczne. W Polsce także działają turystyczne organizacje sieciowe i sieci, które obok innych usług zajmują się m.in. usługami turystycznymi. Jedna z najbardziej popularnych form turystyki to turystyka wiejska, której rozwój uwarunkowany jest różnymi czynnikami, w tym wsparciem otoczenia instytucjonalno-sieciowego.

Rozwój turystyki i rekreacji na obszarach wiejskich w Polsce determinują przede wszystkim walory środowiska przyrodniczego. Obszary cenne przyrodniczo umożliwiają uprawianie różnych form turystyki wiejskiej i są najważniejszym celem przyjazdów turystów na wieś (Sikora 1995, s. 13; Jalinik 2002, s. 41; Knecht 2009, s. 111; Roman, Niedziółka 2017, s. 28). Ważne dla rozwoju turystyki wiejskiej są również walory kulturowe, określane jako antropogeniczne (Buczkowska 2008, s. 56; Żelazna, Orłowski 2008, s. 69; Jędrysiak 2010, s. 31). Podstawą natomiast rozwoju usług turystyczno-rekreacyjnych jest infrastruktura turystyczna, czyli materialna baza turystyki składająca się z bazy noclegowej, gastronomicznej oraz komplementarnej (uzupełniającej), np. szlaków turystycznych, wypożyczalni sprzętu sportowo-turystycznego czy obiektów sportowo-rekreacyjnych.

W zarządzaniu turystyką wiejską ważną rolę odgrywają różne organizacje i podmioty (Zawadka 2010, s. 42; Sawicki, Mazurek-Kuciak 2010, s. 36; Niedziółka, Perchał 2016, s. 165). Można wśród nich wyróżnić władze samorządowe, które zajmują się głównie promocją lokalnych walorów turystycznych i ofertą turystycznowypoczynkową obiektów noclegowych działających w ich gminach (Nawrocka 2001, s. 90; Pawlusiński 2005, s. 23; Sikora 1999, s. 238). W procesach zarządzania turystyką na wsi należy także odnotować rolę ośrodków doradztwa rolniczego. Zajmują się one przede wszystkim kwestiami doradczo-szkoleniowymi w agroturystyce i organizacją kursów agroturystycznych dla rolników planujących założenie gospodarstwa agroturystycznego. Trzeci podmiot zaangażowany $\mathrm{w}$ procesy zarządcze w turystyce wiejskiej to ARiMR, czyli Agencja Restrukturyzacji i Modernizacji Rolnictwa, której zadaniem jest wspieranie rozwoju rolnictwa i obszarów wiejskich, w tym usług turystyczno-rekreacyjnych na wsi. Agencja to podmiot wdrażający instrumenty finansowe $\mathrm{w}$ realizacji projektów z Unii Europejskiej (Skowron-Grabowska, Jasińska 2019, s. 7). Część funduszy unijnych jest przeznaczona na rozwój turystyki wiejskiej, w tym agroturystyki.

Oprócz wymienionych trzech podmiotów rozwojem turystyki wiejskiej zarządzają ponadto inne organizacje, np. organizacje sieciowe (sieci międzyorganizacyjne). Stanowią one przykład współpracy zrzeszonych w nich członków (aktorów) w zakresie rozwoju turystyki na obszarach wiejskich. Można do nich zaliczyć przede 
wszystkim: stowarzyszenia agroturystyczne, lokalne organizacje turystyczne (LOT) oraz lokalne grupy działania (LGD). Wszystkie trzy wymienione organizacje sieciowe zaangażowane są w procesy zarządzania turystyką wiejską i w tym zakresie stosują różne metody i koncepcje zarządzania. Każda z nich odgrywa ważną rolę w zarządzaniu marketingowym w turystyce wiejskiej, głównie w działalności promocyjnej, ale także w kształtowaniu ofert turystycznych na wsi i wdrażaniu kanałów dystrybucji.

W problematyce zarządzania organizacjami aspekty zarządzania organizacjami sieciowymi w turystyce wiejskiej są ważne $\mathrm{i}$ do tej pory nie zbadane na szeroką skalę. Te organizacje non profit stanowią przykład podmiotów zaangażowanych w różne procesy zarządzania w turystyce na obszarach wiejskich. Dotyczy to przede wszystkim zarządzania marketingowego, w tym zarządzania promocją oraz zarządzania strategicznego.

Poddano analizie krytycznej pozycje literatury dotyczące działalności organizacji sieciowych na rynku turystyki wiejskiej w Polsce. Dokonano przeglądu badań nad aktywnością stowarzyszeń agroturystycznych, lokalnych organizacji turystycznych oraz lokalnych grup działania. W pracy przyjęto hipotezę, że organizacje sieciowe w Polsce wspierają rozwój turystyki wiejskiej przede wszystkim w działalności promocyjno-informacyjnej.

\section{Istota organizacji sieciowych $\mathrm{i}$ ich cechy}

W nowej sieciowej koncepcji przedsiębiorstwo stanowi zbiór rozproszonych zespołów połączonych siecią wzajemnych relacji. Zespoły pełnią wobec siebie określone funkcje, zarówno odbiorców, jak i dostawców (Tapscott 1998, s. 63).

W literaturze fachowej można spotkać różne określenia pojęcia „struktura sieciowa". W największym skrócie pisze się po prostu o sieci, rozumianej najogólniej jako system połączeń pomiędzy ludźmi lub jednostkami organizacyjnymi, tworzony w celu wymiany informacji, pomysłów oraz zasobów (Barczak 2016, s. 53). Częstymi sformułowaniami są również „sieć organizacyjna”, „organizacja sieciowa”, „przedsiębiorstwo sieciowe”, „sieć międzyorganizacyjna”.

Generalnie „sieć” rozumiana jest jako system połączeń pomiędzy ludźmi lub przedsiębiorstwami, który tworzony jest $\mathrm{w}$ celu wymiany informacji, pomysłów oraz zasobów. Pojęcie to zostało wprowadzone do nauki przez Johna Barnesa i miało charakter metaforyczny, co wynikało z idei, że społeczne powiązania między jednostkami rozprzestrzeniają się w społeczeństwie na zasadzie sieci, a relacje i powiązania między jednostkami „oplatają” społeczeństwo (Barnes 1954, s. 39-57). M. Castells funkcjonowaniu sieci przypisuje dokonujące się głębokie przemiany współczesnych społeczeństw. Autor ten uważa, że przeobrażenia takie stanowią złożony wynik sieciowej formy organizacji społecznej, w którą włączają się albo są włączane jednostki i grupy społeczne (Castells 2007, s. 19-42).

W literaturze zagranicznej i krajowej można znaleźć bardzo liczne definicje struktur sieciowych, określanych zamiennie jako sieci, organizacje lub przedsiębiorstwa sieciowe czy sieci między- oraz organizacyjne. W Tabeli 1 zaprezentowano przykładowe ich definicje według czterech autorów zagranicznych i czterech krajowych. 
Tabela 1. Przykładowe definicje struktury sieciowej w polskiej i zagranicznej literaturze

\begin{tabular}{|c|c|}
\hline Autorzy & Definicja \\
\hline H.B. Thorelli (1986) & $\begin{array}{r}\text { Sieć jest to układ dwóch lub więcej organizacji } \\
\text { zaangażowanych w długoterminową relację. }\end{array}$ \\
\hline $\begin{array}{c}\text { P. Bianchi, } \\
\text { N. Bellini (1991) }\end{array}$ & $\begin{array}{c}\text { Sieć to interaktywny zespół firm, oparty na zewnętrznym } \\
\text { podziale pracy i niepodlegający zhierarchizowanemu } \\
\text { zarządzaniu. }\end{array}$ \\
\hline C.M. Hall (1999) & Sieć to międzyorganizacyjne porozumienie o współpracy. \\
\hline $\begin{array}{c}\text { A. Bressand, } \\
\text { C. Distler (2002) }\end{array}$ & $\begin{array}{c}\text { Sieć to zbiór środków (infrastruktura) i zasad (infostruktura) } \\
\text { umożliwiających podmiotom, które mają do nich dostęp, } \\
\text { podejmowanie realizacji wspólnych projektów, o ile środki } \\
\text { te są odpowiednie do ich potrzeb i nadają się do wspólnego } \\
\text { wykorzystania (infokultura) przez sieć. }\end{array}$ \\
\hline J. Lichtarski (1993) & $\begin{array}{c}\text { Sieć jest złożoną, wielopodmiotową strukturą, o różnym } \\
\text { stopniu trwałości, spójności i otwartości. }\end{array}$ \\
\hline A. Jewtuchowicz (1997) & $\begin{array}{r}\text { Sieć to zbiór wyselekcjonowanych związków } \\
\text { z wybranymi partnerami wpisującymi się w relacje rynkowe } \\
\text { przedsiębiorstwa. }\end{array}$ \\
\hline J. Góra (2008) & $\begin{array}{r}\text { Organizacja sieciowa jest wiązką odrębnych przedsiębiorstw, } \\
\text { koordynowanych za pomocą mechanizmów rynkowych. }\end{array}$ \\
\hline M. Bratnicki (2000) & $\begin{array}{c}\text { Sieć to nowy styl zarządzania i nowa forma zorganizowania } \\
\text { stosunków między firmami. }\end{array}$ \\
\hline
\end{tabular}

Źródło: Opracowanie własne na podstawie (Bianchi, Bellini 1991, s. 489; Bratnicki 2000, s. 275; A. Bressand i C. Distler - cyt. za: Brilman (2002), s. 43; Góra 2008, s. 13; Hall 1999,

s. 179; Jewtuchowicz 2012, s. 13; Lichtarski 1993, s. 17; Thorelli 1986, s. 37)

Przedsiębiorstwo sieciowe stanowi zbiór niezależnych w sensie prawnym jednostek gospodarczych, realizujących różnorodne przedsięwzięcia i projekty koordynowane przez firmę-integratora, która ma wyróżniające ją (kluczowe, podstawowe) kompetencje (Perechuda 2007, s. 55). Cechami głównymi przedsiębiorstwa sieciowego są natomiast (Perechuda 2007, s. 55-56):

- dobrowolność przystąpienia do sieci,

- równoległa realizacja różnorodnych projektów i przedsięwzięć gospodarczych,

- kompatybilność kompetencji firmy-integratora oraz pozostałych kooperantów,

- coraz krótsze cykle życia produktów i usług,

- przenikanie się z innymi sieciami,

- duży potencjał organizacyjnego uczenia się.

Każda organizacja wchodząca w skład sieci realizuje grupy zadań, stanowiących najczęściej wspólne przedsięwzięcia podejmowane przez aktorów w przedsiębiorstwie sieciowym. 
Organizacje sieciowe pełnią w Polsce istotną rolę w zarządzaniu turystyką na obszarach wiejskich. Tworzą ciekawe, sieciowe oferty wypoczynku na wsi, prowadzą politykę promocyjną oraz współdziałają ze sobą na różnych polach w sektorze turystyczno-rekreacyjnym. Również ich członkowie, aktorzy sieciowi, wśród których licznie występują obiekty noclegowe, kooperują między sobą w ramach jednej sieci, np. stowarzyszenia agroturystycznego.

\section{Organizacje sieciowe w procesach zarządzania turystyką wiejską}

Zarządzanie turystyką wiejską jest wielopłaszczyznowym działaniem dotyczącym wdrażania funkcji zarządzania: planowania, organizowania, koordynowania, przewodzenia i kontrolowania w zakresie rozwoju usług turystycznych na wsi. Zarządzanie turystyką wiejską związane jest $\mathrm{z}$ realizacją różnych przedsięwzięć marketingowo-strategicznych na wiejskim rynku turystycznym. Instytucjami zarządzającymi usługami turystycznymi na obszarach wiejskich mogą być obiekty hotelarskie i noclegowe, organizacje turystyczne, w tym sieciowe, jak stowarzyszenia agroturystyczne i lokalne organizacje turystyczne, oraz samorządy gminne, ośrodki doradztwa rolniczego.

Najbardziej znanymi organizacjami sieciowymi zarządzającymi rozwojem turystyki wiejskiej są stowarzyszenia agroturystyczne. Można je określić jako dobrowolne, samorządne i trwałe zrzeszenia o celach niezarobkowych, dotyczących rozwoju usług turystycznych na wsi. Najważniejszym zadaniem stowarzyszeń jest promocja turystyki na obszarach wiejskich, w tym agroturystyki. Od maja 2016 roku, aby założyć stowarzyszenie, potrzeba 7 osób (wcześniej przez długi okres wymogiem było 15 osób) (https://publicystyka.ngo.pl/...).

Stowarzyszenia są powoływane do realizacji celów wyszczególnionych w ich statutach. Do celów statutowych często zalicza się informowanie potencjalnych turystów o walorach turystycznych danego regionu oraz prowadzenie działań promocyjnych, przede wszystkim w oparciu o publikacje oraz mapy, broszury i informatory (Sznajder, Przezbórska 2006, s. 136).

Do najważniejszych zadań stowarzyszeń agroturystycznych można zaliczyć (Kania, Leśniak, Musiał 2005, s. 115-116):

- prowadzenie marketingu usług agroturystycznych, głównie promocji,

- kształtowanie ofert dla różnych grup turystów,

- działalność doradczo-szkoleniową dla swoich członków,

- badanie rynku turystycznego na obszarach wiejskich,

- współpracę z samorządami i administracją rządową w kontekście opracowania strategii rozwoju agroturystyki,

- uruchomienie systemu rezerwacji oraz organizowanie sprzedaży produktu wraz $\mathrm{z}$ ujednoliceniem polityki cen.

Drugą turystyczną siecią międzyorganizacyjną są LOT-y, czyli lokalne organizacje turystyczne. Są one organizacjami współpracy jednostek samorządu terytorialnego (gmin i powiatów) i lokalnej branży turystycznej. LOT-y powołuje się do życia w obrębie obszarów atrakcyjnych turystycznie, posiadających wybitne walory środowisk przyrodniczych oraz kulturowych (Borzyszkowski 2012, s. 82). Przewiduje się, że członkami lokalnych organizacji turystycznych powinny być (Migdał 2007, s. 27): 
- urzędy miast i gmin, na terenie których funkcjonuje LOT,

- lokalne organizacje branżowe - np. stowarzyszenia i fundacje,

- wszystkie podmioty gospodarcze prowadzące działalność w zakresie usług turystyczno-rekreacyjnych.

Lokalne organizacje turystyczne są tworzone w formie stowarzyszeń. Działają na obszarze jednostek samorządu terytorialnego (najczęściej jednej lub kilku gmin lub powiatów posiadających różne atrakcje turystyczne), które są w nich zrzeszone (Szymańska 2008, s. 124). LOT-y są aktywne przede wszystkim na obszarach wiejskich i propagują wypoczynek na wsi u swoich członków, np. pobyty w gospodarstwach agroturystycznych. Do najważniejszych zadań LOT-ów należą (Jalinik 2016, s. 76):

- integracja społeczności lokalnej, głównie jednostek samorządu lokalnego i branży turystycznej,

- kreowanie produktu turystycznego, jego rozwój i promocja wokół lokalnych walorów turystycznych,

- gromadzenie oraz aktualizacja informacji o atrakcjach i produktach turystycznych,

- utrzymanie i prowadzenie lokalnych punktów informacji turystycznej.

Stowarzyszenia agroturystyczne i lokalne organizacje turystyczne to typowe organizacje sieciowe, które w procesach zarządzania turystyką wiejską odgrywają kluczową rolę. Przede wszystkim zarządzają działalnością promocyjną, wspierając w tym swoich członków, zarówno obiekty noclegowe, np. gospodarstwa agroturystyczne w przypadku głównie stowarzyszeń, jak i urzędy gmin wiejskich, w przypadku LOT-ów. Warto jeszcze nadmienić, że oba podmioty, mimo iż są organizacjami o charakterze niezarobkowym, mogą prowadzić działalność gospodarczą. Nierzadko lokalne organizacje turystyczne taką działalność prowadzą np. w formie działalności wydawniczej książek poświęconych walorom turystycznym, opracowania stron WWW czy przeprowadzanych analiz dla przedsiębiorstw turystycznych (Stec 2008, s. 366).

Trzecią organizacją sieciową, tym razem niebędącą wyłącznie organizacją o profilu turystycznym, jest LGD, czyli lokalna grupa działania. Organizacje LGD powstawały w celu wdrażania lokalnych strategii rozwoju na obszarze ich funkcjonowania. Praktycznym warunkiem funkcjonowania LGD było pozyskanie środków na realizację przygotowanych uprzednio strategii. W tym celu każda zainteresowana uzyskaniem takiego wsparcie lokalna grupa działania zobowiązana była do wzięcia udziału w procedurze konkursowej organizowanej na poziomie całego kraju przez Fundację Programów Pomocy dla Rolnictwa, a w późniejszym okresie przez poszczególne samorządy województw (Turek 2013, s. 407).

Głównymi celami działań lokalnych grup działania są (Jalinik 2016, s. 81):

- aktywizacja gospodarcza regionu wraz z poprawą poziomu życia jego mieszkańców,

- budowa systemu zagospodarowania turystycznego regionu,

- ochrona środowiska przyrodniczego i racjonalne wykorzystanie zasobów naturalnych,

- organizacja konkursów i szkoleń w ramach działalności nierolniczej, w tym działalności agroturystycznej, 
- pomoc doradcza w prowadzeniu działalności przedsiębiorczej na obszarach wiejskich,

- promocja regionu przy zachowaniu jego wartości przyrodniczych oraz kulturowych,

- rozwijanie wszechstronnej współpracy transgranicznej.

Bardzo często w lokalnych strategiach rozwoju zapisane są działania skierowane na sektor turystyki wiejskiej. Dotyczą one szeroko rozumianego marketingu, przede wszystkim kształtowania nowych produktów turystycznych, współpracy oferentów usług noclegowych na wsi oraz wdrażania różnych kanałów dystrybucji. Ważną kwestią są również działania promocyjne, które stanowią podstawę rozwoju usług turystyczno-rekreacyjnych na obszarach wiejskich.

Omówione trzy organizacje sieciowe, które zarządzają rozwojem turystyki wiejskiej, mają wiele cech wspólnych. Po pierwsze, zarówno lokalne organizacje turystyczne, jak i lokalne grupy działania najczęściej są powoływane do życia w formie stowarzyszeń, tak samo jak każde stowarzyszenie agroturystyczne. W przypadku LOT-ów oraz stowarzyszeń zrzeszających przede wszystkim gospodarstwa agroturystyczne - ich najważniejszymi zadaniami są promocja walorów turystycznych obszarów, na których działają, oraz promowanie ofert noclegowo-wypoczynkowych swoich członków.

W Tabeli 2 przedstawiono liczbę działających w 2019 roku lokalnych organizacji turystycznych, lokalnych grup działania oraz stowarzyszeń agroturystycznych i przykładowych członków.

Tabela 2. Organizacje sieciowe dzialające na rynku turystyki wiejskiej w 2019 roku oraz przykladowi ich czlonkowie

\begin{tabular}{|c|c|c|}
\hline Organizacja & Liczba & Przykladowi czlonkowie \\
\hline $\begin{array}{c}\text { Stowarzyszenie } \\
\text { agroturystyczne }\end{array}$ & 159 & $\begin{array}{r}\text { Gospodarstwa agroturystyczne, pensjonaty, domy } \\
\text { wypoczynkowe, stadniny koni. }\end{array}$ \\
\hline $\begin{array}{c}\text { Lokalna organizacja } \\
\text { turystyczna (LOT) }\end{array}$ & 121 & $\begin{array}{c}\text { Urzędy marszałkowskie, gminy miejskie, gminy } \\
\text { miejsko-wiejskie, gminy wiejskie, podmioty } \\
\text { gospodarcze (np. obiekty hotelarskie i noclegowe), } \\
\text { stowarzyszenia, fundacje. }\end{array}$ \\
\hline $\begin{array}{c}\text { Lokalna grupa } \\
\text { działania (LGD) }\end{array}$ & 324 & $\begin{array}{c}\text { Osoby fizyczne, stowarzyszenia, kluby sportowe, } \\
\text { ochotnicza straż pożarna, urzędy pracy, wyższe } \\
\text { uczelnie. }\end{array}$ \\
\hline
\end{tabular}

Źródło: Opracowanie własne na podstawie (http://cdr112.e-kei.pl/...; https://www.pot.gov.pl/...; http://ksow.pl/...)

$\mathrm{Z}$ analizy Tabeli 2 wynika wyraźnie, że członkami organizacji sieciowych zaangażowanych w procesy zarządzania turystyką wiejską są różne podmioty. Mogą to być zarówno obiekty noclegowe, jak i np. gminy. Warto jeszcze nadmienić, że niekiedy jeden podmiot, np. gospodarstwo agroturystyczne, może być członkiem za- 
równo LGD, jak i stowarzyszenia. Bardzo rzadko natomiast zdarza się, że jeden podmiot należy do wszystkich trzech organizacji sieciowych, ponieważ wiąże się to z dużymi wydatkami na składki członkowskie.

\section{Przegląd badań nad organizacjami sieciowymi zarządzającymi rozwojem turystyki wiejskiej}

Aspekty zarządzania turystyką wiejską dotyczą działalności różnych podmiotów oraz organizacji sieciowych. W okresie ostatnich około 20 lat wielu badaczy podejmowało się badań nad aspektami zarządczo-marketingowymi sieci w kontekście rozwoju usług turystycznych na wsi.

Przegląd badań nad przedsiębiorstwami sieciowymi można rozpocząć od badań nad działalnością stowarzyszeń agroturystycznych. $Z$ jednej strony dotyczyły one funkcjonowania pojedynczych stowarzyszeń, a z drugiej - korzyści, jakie czerpią ich członkowie z tytułu przynależności do nich. W drugim przypadku najczęściej badano zrzeszone gospodarstwa agroturystyczne.

Badania dotyczące zarządzania turystyka wiejską, w tym agroturystyką przez stowarzyszenia agroturystyczne, realizowali liczni autorzy, począwszy od lat 90. XX wieku. Dla przykładu: M. Lechwar i P. Filip określiły aspekty zarządczo-marketingowe w działalności Stowarzyszenia Agroturystycznego Regionu „Dolina Strugu" w województwie podkarpackim (Lechwar, Filip 1998, s. 141). Organizacja zarządzała turystyką wiejską głównie poprzez wdrażanie instrumentów promocyjnych, a także w prowadzeniu doradztwa dotyczącego kształtowania polityki cenowej w zrzeszonych gospodarstwach agroturystycznych. Ponadto „Dolina Strugu” zarządzała jakością ofert agroturystycznych poprzez kontrolowanie standardów i jakości świadczonych usług przez swoich członków, prowadziła dla nich szkolenia oraz pielęgnowała regionalne tradycje ludowe (Lechwar, Filip 1998, s. 141). Podobne wyniki badań uzyskał Arkadiusz Niedziółka, który badaniom ankietowym poddał prezesów dwóch stowarzyszeń agroturystycznych z województwa małopolskiego: Góralskiego Stowarzyszenia Agroturystycznego oraz Stowarzyszenia Turystyki i Agroturystyki Ziem Górskich. Również w tym przypadku zarządzanie marketingowe w agroturystyce było najczęściej stosowaną koncepcją zarządzania przez władze obydwu stowarzyszeń. Badani wskazali ponadto na zarządzanie jakością oraz zarządzanie strategiczne w aspektach realizacji celów strategicznych swoich organizacji (Niedziółka 2017, s. 117-123).

Badania mające natomiast na celu określenie korzyści wynikających z członkostwa w stowarzyszeniach agroturystycznych przeprowadzili M. Karczewska i J. Sikora. Badaniom ankietowym poddali oni 67 właścicieli gospodarstw agroturystycznych w województwie wielkopolskim (Karczewska, Sikora 2005, s. 199). Wśród wymienianych korzyści zrzeszeni usługodawcy wskazywali na: dostępność informacji ułatwiających prowadzenie działalności agroturystycznej (57,4\% przypadków), możliwość otrzymania pomocy doradczej $(39,4 \%)$ oraz na dobrze zorganizowaną promocję usług (33\%) (Karczewska, Sikora 2005, s. 199). Podobne badania ankietowe przeprowadził A. Niedziółka na grupie 184 rolników zajmujących się agroturystyką w województwie małopolskim (Niedziółka 2008, s. 77). Okazało się, 
że wśród wymienianych przez nich korzyści płynących z członkostwa w stowarzyszeniach agroturystycznych $86 \%$ badanych wskazało na promocję, $24 \%$ na szkolenia, a $19 \%$ na dostęp do informacji (Niedziółka 2008, s. 77). Dużą próbą badawczą wykazał się w podobnych badaniach M. Jalinik, który przebadał aż 313 zrzeszonych właścicieli gospodarstw agroturystycznych z obszaru dwóch województw: podlaskiego i warmińsko-mazurskiego (Jalinik 2005, s. 22). Także i w tym przypadku większość badanych wskazywała na wspólną działalność promocyjną jako najważniejszą korzyść wynikającą z przynależności do stowarzyszeń.

Również na gruncie ustawy o stowarzyszeniach, na podstawie której funkcjonują stowarzyszenia agroturystyczne, działają inne sieciowe organizacje turystyczne, mianowicie lokalne organizacje turystyczne, w skrócie LOT-y. W ostatnich dwóch dekadach, podobnie jak w przypadku stowarzyszeń agroturystycznych, również i im poświęcono w pracach badawczych sporo uwagi.

W 2010 roku Polska Organizacja Turystyczna przeprowadziła badania dotyczące współpracy między sobą lokalnych organizacji turystycznych oraz ich kooperacji z innymi podmiotami, niekoniecznie organizacjami sieciowymi. Przebadano łącznie 73 LOT-y działające na terenie całego kraju. Wśród ich członków zdecydowanie dominowali przedsiębiorcy (51\%), następnie inne podmioty (23\%) oraz samorządy (11\%). Działalność lokalnych organizacji turystycznych koncentrowała się głównie na tworzeniu i prowadzeniu informacji turystycznej oraz kształtowaniu lokalnych produktów turystycznych o charakterze sieciowym. Sieciowość produktów dotyczyła tworzenia wspólnych ofert członków poszczególnych LOT-ów (Wanagos 2011, s. 286-287). Widać zatem, że zarządzanie marketingowe stanowi meritum $\mathrm{w}$ procesach zarządzania turystyką wiejską $\mathrm{w}$ działalności tych organizacji. Badani aktorzy lokalnych organizacji turystycznych wśród korzyści wynikających ze współpracy ich LOT-u z innymi podmiotami wymieniali: wymianę doświadczeń (41\%), wspólną promocję $(40 \%)$, wspólne projekty $(18 \%)$, kreację produktów $(14 \%)$, wizyty studyjne (8\%) oraz pozyskiwanie środków (8\%) (Wanagos 2011, s. 289).

Z kolei w 2013 roku A. Stefanowska i M. Lipko-Kowalska przesłały drogą elektroniczną ankiety do wszystkich 130 działających wówczas w Polsce lokalnych organizacji turystycznych. Ankiety wypełnili przedstawiciele 30 LOT-ów w liczbie 88 osób (Stefanowska, Lipko-Kowalska 2017, s. 102). Respondenci określili korzyści wynikające z członkostwa w LOT-ach. Najczęściej były one związane z korzyściami marketingowymi $(38,56 \%)$, mianowicie ze skonsolidowanymi działaniami, m.in. wspólnymi udziałami w targach turystycznych, organizowaniem wspólnym imprez, zapewnieniem tańszej promocji, możliwością udziału w warsztatach i szkoleniach oraz możliwością bezpłatnej prezentacji ofert i katalogów w Centrach Informacji Turystycznej (Stefanowska, Lipko-Kowalska 2017, s. 111). Największe grono ankietowanych członków LOT-ów, bo aż 78\%, angażowało się w działania promocyjne swojej organizacji. Ponad połowa badanych (56\%) uczestniczyła także w tworzeniu produktów turystycznych mających na celu przyciągnięcie jak największej liczby turystów oraz poprawę wizerunku regionu, w którym lokalna organizacja turystyczna działała (Stefanowska, Lipko-Kowalska 2017, s. 111). Wyniki te potwierdzają, że w aspektach zarządzania turystyką najważniejsze miejsce w działalności 
lokalnych organizacji turystycznych zajmuje koncepcja zarządzania marketingowego, przede wszystkim zarządzanie promocją.

Trzecią grupą organizacji sieciowych działających tylko na terenach wiejskich, które również zarządzają rozwojem usług turystycznych na wsi, są lokalne grupy działania. Organizacje te bardzo często w rozwoju usług turystycznych widzą możliwość rozwiązania wielu problemów społeczno-gospodarczych na obszarach swojej działalności. W ich lokalnych strategiach rozwoju zapisane są różne działania i postulaty dotyczące rozwoju turystyki wiejskiej, w tym zagospodarowania turystycznego i marketingu. W zarządzaniu marketingowym na czoło wysuwają się kwestie tworzenia produktów sieciowych, nowych ofert noclegowych i usług rekreacyjnych. Bardzo duży nacisk LGD kładą na działalność promocyjną (Boba 2013, s. 100-104; Starmach 2013, s. 133-144; Kowalska 2013, s. 188-198).

Potwierdzeniem stosowania i wdrażania przez LGD koncepcji zarządzania marketingowego są badania przeprowadzone z przedstawicielami 10 lokalnych grup działania z województwa wielkopolskiego, na terenie działalności których znajdują się parki krajobrazowe (Maćkowiak, Graja-Zwolińska, Spychała 2017, s. 190-197). W procesach zarządzania turystyką wiejską wszystkie poddane badaniom lokalne grupy działania prowadziły szeroką i zróżnicowaną działalność marketingową. Przede wszystkim dotyczyła ona promocji walorów przyrodniczych i kulturowych będących pod ustawową ochroną oraz wypoczynku w obiektach świadczących usługi noclegowe i równocześnie będących członkami badanych LGD. W zakresie aspektów zarządczych badane grupy kładły duży nacisk na kwestie ochrony środowiska przyrodniczego, rozwój zagospodarowania turystycznego w ujęciu koncepcji rozwoju zrównoważonego. Ponadto podmioty te realizowały różne przedsięwzięcia inwestycyjne w sektorze usług turystyczno-rekreacyjnych i planowały w przyszłości realizację nowych. Współpracowały między sobą w działalności promocyjnej oraz w innych przedsięwzięciach (Maćkowiak, Graja-Zwolińska, Spychała 2017, s. 190-197).

Także wyniki badań z przedstawicielami małopolskich lokalnych grup działania mocno potwierdzają, że działalność marketingowa, głównie promocyjna, w zarządzaniu turystyką wiejską jest priorytetem ich aktywności (Turek 2013, s. 408-413).

\section{Podsumowanie}

W zarządzaniu turystyką wiejską w Polsce ważną rolę pełnią różne podmioty, instytucje, a także turystyczne organizacje sieciowe. Są to specyficzne organizacje, które zrzeszają różnych członków, ale najczęściej osoby prowadzące obiekty noclegowe, np. rolników prowadzących działalność agroturystyczną.

Organizacjami bezpośrednio i całkowicie zaangażowanymi w procesy zarządzania turystyką na obszarach wiejskich są stowarzyszenia agroturystyczne. Do ich powołania potrzeba obecnie tylko 7 osób. W praktyce okazuje się, że najczęściej członkami stowarzyszeń są rolnicy prowadzący gospodarstwa agroturystyczne. Wśród innych aktorów tych organizacji zdarzają się m.in. właściciele wiejskich pensjonatów, domów wycieczkowych, a także obiekty, które w ogóle nie oferują turystom 
noclegów. Stowarzyszenia agroturystyczne zarządzają głównie działalnością promocyjną w turystyce wiejskiej, koncentrując się przede wszystkim na promocji walorów turystycznych oraz ofert noclegowo-wypoczynkowych swoich członków.

W procesach zarządzania turystyką na obszarach wiejskich uczestniczą również LOT-y, czyli lokalne organizacje turystyczne. One, podobnie jak stowarzyszenia agroturystyczne, najczęściej wdrażają w życie różne koncepcje zarządzania marketingowego, szczególnie angażują się w działalność promocyjną. Wśród członków LOT-ów można wyróżnić obiekty noclegowe, urzędy miast i gmin, stowarzyszenia oraz fundacje.

Trzecim przedsiębiorstwem sieciowym uczestniczącym w procesach zarządzania usługami turystycznymi na wsi są lokalne grupy działania (LGD). Podobnie jak w przypadku stowarzyszeń oraz LOT-ów, lokalne grupy działania najbardziej koncentrują się na promocji turystyki wiejskiej. Niekiedy ich członkowie współpracują również w tworzeniu sieciowych produktów turystycznych.

Oprócz najczęściej stosowanego zarządzania marketingowego w turystyce wiejskiej przez trzy opisane w niniejszym opracowaniu organizacje sieciowe często dodatkowo koncepcję zarządzania strategicznego wdrażają lokalne grupy działania. $\mathrm{W}$ opracowywanych przez nie lokalnych strategiach rozwoju usługi rekreacyjno-turystyczne bardzo często stanowią podstawę planowanych przedsięwzięć strategicznych. Wiele obszarów, na których działają LGD, to typowe obszary cenne przyrodniczo cechujące się występowaniem licznych atrakcji krajobrazowych.

Na podstawie przeglądu literatury i wyników badań różnych autorów należy pozytywnie zweryfikować hipotezę o wsparciu turystyki wiejskiej przez organizacje sieciowe przede wszystkim w działalności promocyjno-informacyjnej.

\section{Literatura}

1. Barczak B. (2016), Koncepcja oceny efektywności struktur sieciowych, Wydawnictwo Uniwersytetu Ekonomicznego w Krakowie, Kraków.

2. Barnes J. (1954), Class and Committees in a Norwegian Island Parish, „Human Relations”, nr 7.

3. Bianchi P., Bellini N. (1991), Public Policies for Local Networks of Innovators, „Research Policy", Vol. 20(5).

4. Boba K. (2013), Stowarzyszenie Lokalna Grupa Działania „Beskid Gorlicki”, [w:] Puchała J., Kowalska M. (red.), Rola i znaczenie Lokalnych Grup Działania w rozwoju obszarów wiejskich w Polsce, Wydawnictwo Adam Marszałek, Torun.

5. Borzyszkowski J. (2012), Organizacja i zarzadzanie turystyka w Polsce, CeDeWu, Warszawa.

6. Bratnicki M. (2000), Zaproszenie do medytacji o granicach przedsiębiorstwa, „Prace Naukowe Akademii Ekonomicznej we Wrocławiu", nr 851.

7. Brilman J. (2002), Nowoczesne koncepcje i metody zarządzania, PWE, Warszawa.

8. Buczkowska K. (2008), Turystyka kulturowa. Przewodnik metodyczny, Wydawnictwo Akademii Wychowania Fizycznego w Poznaniu, Poznań.

9. Castells M. (2007), Spoleczeństwo sieci, Wydawnictwo Naukowe PWN, Warszawa.

10. Czakon W. (2012), Sieci w zarzadzaniu strategicznym, Wolters Kluwer, Warszawa.

11. Góra J. (2008), Dynamika klastra - zarys teorii i metodyka badań, Wyższa Szkoła Handlowa, Wrocław.

12. http://cdr112.e-kei.pl/agroturystyka/images/Baza_stowarzyszen_at.pdf(dostęp: 19.04.2020)

13. http://ksow.pl/baza-lgd-2014-2020.html?no_cache- $=1$ (dostęp: 19.04.2020).

14. https://www.pot.gov.pl/attachments/article/1732/Lokalne\%20Organizacje\%20Turystyczne_ 24.10.2019.pdf (dostęp: 19.04.2020). 
15. https://publicystyka.ngo.pl/juz-niedlugo-stowarzyszenie-bedzie-moglo-zalozyc-7-osob (dostęp: 17.04.2020).

16. Hall C.H. (1999), Rethinking Collaboration and Partnership: A Public Policy Perspective, „Journal of Sustainable Tourism”, Vol. 7(3).

17. Jalinik M. (2002), Agroturystyka na obszarach przyrodniczo cennych, Wydawnictwo Politechniki Białostockiej, Białystok.

18. Jalinik M. (2005), Typologia gospodarstw agroturystycznych jako determinanta rozwoju, Wydawnictwo Politechniki Białostockiej, Białystok.

19. Jalinik M. (2016), Doradztwo w działalności turystycznej, Zamiejscowy Wydział Leśny Politechniki Białostockiej w Hajnówce, Białystok.

20. Jewtuchowicz A. (2012), Terytorium $i$ jego rozwój $w$ warunkach globalizacji, [w:] Molendowski E. (red.), Globalizacja i regionalizacja we współczesnym świecie. Księa jubileuszowa dedykowana Profesor Irenie Pietrzyk, Wydawnictwo Uniwersytetu Ekonomicznego w Krakowie, Kraków.

21. Jędrysiak T. (2010), Wiejska turystyka kulturowa, PWE, Warszawa.

22. Kania J., Leśniak L., Musiał W. (2005), Agroturystyka i ustugi towarzyszace, Małopolskie Stowarzyszenie Doradztwa Rolniczego, Kraków.

23. Karczewska M., Sikora J. (2005), Działalność lokalnych stowarzyszeń agroturystycznych w opinii kwaterodawców, [w:] Kryński Z., Kmita-Dziasek E. (red.), Turystyka wiejska a rozwój $i$ wspótpraca regionów, Wydawnictwo Państwowej Wyższej Szkoły Zawodowej w Krośnie, Krosno.

24. Knecht D. (2009), Agroturystyka w agrobiznesie, C.H. Beck, Warszawa.

25. Kowalska M. (2013), Stowarzyszenie Lokalna Grupa Działania „,Naszyjnik Pótnocy”, [w:] Puchała J., Kowalska M. (red.), Rola i znaczenie Lokalnych Grup Działania w rozwoju obszarów wiejskich w Polsce, Wydawnictwo Adam Marszałek, Toruń.

26. Lechwar M., Filip P. (1998), Rola lokalnych stowarzyszeń agroturystycznych $w$ promocji turystyki wiejskiej, [w:] Wiatrak A.P. (red.), Marketing i produkty markowe $w$ turystyce wiejskiej, Centrum Doradztwa i Edukacji w Rolnictwie w Poznaniu, Poznań.

27. Lichtarski J. (1993), Współdziałanie gospodarcze przedsiębiorstw, PWE, Warszawa.

28. Maćkowiak M., Graja-Zwolińska S., Spychała A. (2017), Aktywność lokalnych grup działania jako wsparcie rozwoju turystyki na obszarach chronionych, „Folia Turistica”, nr 42.

29. Migdał M. (2007), ROT i LOT jako instrumenty polityki turystycznej - wstęp do analizy struktury formalno-prawnej oraz zasad zwyczajowych funkcjonowania ROT i LOT, „Rocznik Naukowy Wyższej Szkoły Turystyki i Rekreacji im. M. Orłowicza w Warszawie”, t. 6/2007.

30. Nawrocka E. (2001), Znaczenie władz lokalnych w rozwoju agroturystyki, [w:] Klepacki B. (red.), Turystyka wiejska czynnikiem ożywienia terenów wiejskich, Krajowe Centrum Doradztwa Rozwoju Rolnictwa i Obszarów Wiejskich Oddział w Krakowie, Kraków.

31. Niedziółka A. (2008), Działalność stowarzyszeń agroturystycznych jako ważna determinanta rozwoju agroturystyki w województwie małopolskim, „Folia Universitatis Agriculturae Stetinensis. Oeconomica", t. 51.

32. Niedziółka A. (2017), Stan i czynniki rozwoju usług agroturystycznych $w$ powiecie nowotarskim $w$ perspektywie wsparcia agroturystyki z programów Unii Europejskiej w latach 2014-2020, Stowarzyszenie Naukowe Instytutu Gospodarki i Rynku, Kraków.

33. Niedziółka A., Perchał A. (2016), Działalność promocyjna stowarzyszeń agroturystycznych na przykładzie Małopolski, [w:] Jęczmyk A., Uglis J., Maćkowiak M. (red.), Turystyka wiejska. Zagadnienia ekonomiczne i marketingowe, t. 1, Wydawnictwo Wieś Jutra, Poznań.

34. Oleksiuk A. (2007), Marketing ustug turystycznych, Difin, Warszawa.

35. Pawlusiński R. (2005), Samorząd lokalny a rozwój turystyki. Przykład gmin Wyżyny Krakowsko-Częstochowskiej, Instytut Geografii i Gospodarki Przestrzennej Uniwersytetu Jagiellońskiego, Kraków.

36. Perechuda K. (2007), Dyfuzja wiedzy w przedsiębiorstwie sieciowym. Wizualizacja i kompozycja, Wydawnictwo Akademii Ekonomicznej im. Oskara Langego we Wrocławiu, Wrocław. 
37. Roman M., Niedziółka A. (2017), Agroturystyka jako forma przedsiębiorczości na obszarach wiejskich, Wydawnictwo SGGW, Warszawa.

38. Sawicki B., Mazurek-Kuciak A.K. (2010), Agroturystyka w teorii i praktyce, Wydawnictwo Uniwersytetu Przyrodniczego, Lublin.

39. Sikora J. (1995), Agroturystyczny biznes, Oficyna Wydawnicza Ośrodka Postępu Organizacyjnego, Bydgoszcz.

40. Sikora J. (1999), Organizacja ruchu turystycznego na wsi, Wydawnictwa Szkolne i Pedagogiczne, Warszawa.

41. Skowron-Grabowska B., Jasińska K. (2019), Zarzadzanie wiedza w projektach organizacji oświatowych $w$ województwie śląskim, Wydawnictwo Politechniki Częstochowskiej, Częstochowa.

42. Starmach M. (2013), Stowarzyszenie Lokalna Grupa Działania „Dorzecze Bobrzy”, [w:] Puchała J., Kowalska M. (red.), Rola i znaczenie Lokalnych Grup Działania w rozwoju obszarów wiejskich $w$ Polsce, Wydawnictwo Adam Marszałek, Toruń.

43. Stec P. (2008), Lokalne i regionalne organizacje turystyczne jako stowarzyszenia szczególnego rodzaju, [w:] Raciborski J., Cybula P. (red.), Turystyka a prawo. Aktualne problemy legislacyjne i konstrukcyjne, Wydawnictwo Wyższej Szkoły Turystyki i Ekologii w Suchej Beskidzkiej, Sucha Beskidzka - Kraków.

44. Stefanowska A., Lipko-Kowalska M. (2017), Lokalne organizacje turystyczne jako czynnik rozwoju regionalnego - ocena funkcjonalna, „Prace Geograficzne”, z. 149.

45. Sznajder M., Przezbórska L. (2006), Agroturystyka, PWE, Warszawa.

46. Szymańska E. (2008), Biura podróży na rynku usług turystycznych, Wydawnictwo Politechniki Białostockiej, Białystok.

47. Tapscott D. (1998), Gospodarka cyfrowa. Nadzieje i niepokoje ery świadomości systemowej, Business Press, Warszawa.

48. Thorelli H.B. (1986), Networks: Between Markets and Hierarchies, „Strategic Management Journal", $\mathrm{nr} 7$.

49. Turek M. (2013), Rola lokalnych grup działania $w$ zarzadzaniu rozwojem lokalnym na przyktadzie matopolskich LGD w perspektywie finansowej 2007-2013, „Zarządzanie Publiczne", nr 4(24).

50. Wanagos M. (2011), Regionalne i lokalne organizacje turystyczne: system relacji i powiazań marketingu wewnętrznego regionu, „Zeszyty Naukowe Uniwersytetu Szczecińskiego. Ekonomiczne Problemy Usług", nr 75.

51. Zawadka J. (2010), Ekonomiczno-spoleczne determinanty rozwoju agroturystyki na Lubelszczyźnie, Wydawnictwo SGGW, Warszawa.

52. Żelazna K., Orłowski D. (2008), Wykorzystanie elementów dziedzictwa kulturowego $w$ tworzeniu oferty turystyki wiejskiej, [w:] Gutkowska K. (red.), Spoteczno-ekonomiczne uwarunkowania agroturystyki, Mazowiecki Ośrodek Doradztwa Rolniczego w Warszawie, Warszawa.

\title{
NETWORK ORGANIZATIONS IN RURAL TOURISM MANAGEMENT PROCESSES
}

\begin{abstract}
Tourist network organizations and other networks participate in rural tourism management processes in Poland, using various concepts and management methods. The most active network organizations managing the development of tourism in rural areas include: agritourism associations, local tourist organizations and local action groups. The aim of the work is to determine the most commonly used management concepts in rural
\end{abstract}

Keywords: network organizations, management, rural tourism, agritourism 